\title{
TREN DAN ISU KESELAMATAN PASIEN
}

\section{MEGA CERIA PURNAMA ZEBUA}

\author{
Megaceria25@gmail.com
}

\begin{abstract}
ABSTRAK
Latar Belakang. Latar belakang penelitian ini adalah bahwa setiap tindakan medis menyimpan potensi resiko. Keselamatan pasien menjadi isu yang sangat disukai oleh khalayak umum. Karena keselamatan pasien salah satu indikator penilaian terhadap suatu rumah sakit. Oleh karena itu rumah sakit dituntut agar mampu mengelola kegiatannya dengan mengutamakan pada tanggung jawab para professional di bidang kesehatan, khususnya tenaga medis dan tenaga keperawatan dalam menjalankan tugas dan kewenangannya. Tidak selamanya layanan medis yang diberikan oleh tenaga kesehatan dapat memberikan hasil yang sebagaimana diharapkan semua pihak. Tenaga kesehatan yang melakukan kelalaian dapat dapat disebut melakukan malpraktik. Tujuan:agar dapat lebih mengerti apa sih keselamatan pasien itu? Apa hal hal yang mempengaruhi pelayanan tersebut? Metode: Penelitian ini menggunakan jenis penelitian explanatory research Kesimpulan: Keselamatan Pasien menjadi Isu dan Tren yang sangat sering di bahas. Keselamatan pasien bergantung kepada pemberi pelayanannya seperti perawat, dokter, tenaga medis yang lain. Semakin tinggi pengetahuan yang dimiliki perawat dalam melakukan tindakan, maka semakin besar angka keselamatan pasien
\end{abstract}

Kata Kunci: keselamatan pasien, K3RS, komunikasi SBAR 


\section{LATAR BELAKANG}

Latar belakang penelitian ini adalah bahwa setiap tindakan medis menyimpan potensi resiko. Banyaknya jenis obat, jenis pemeriksaan dan prosedur, serta jumlah pasien dan staf Rumah Sakit yang cukup besar terutama untuk tenaga perawat yang memiliki jumlah terbesar dalam jumlah kepegawaian rumah sakit, merupakan hal yang potensial bagi terjadinya kesalahan medis (medical errors). Tenaga perawat merupakan tenaga profesional yang berperan penting dalam fungsi rumah sakit. Hal tersebut didasarkan atas jumlah tenaga perawat sebagai porsi terbesar didalam pelayanan rumah sakit.

Dalam menjalankan fungsinya, perawat merupakan staf yang memiliki kontak terbanyak dengan pasien. Perawat juga merupakan bagian dari suatu tim, yang didalamnya terdapat berbagai profesional lain seperti dokter. Luasnya peran perawat memungkinkannya terjadinya risiko kesalahan pelayanan (Cahyono, Hubungan Karakteristik dan Tingkat Pengetahuan Perawat Terhadap Pengelolaan Keselamatan Pasien di Rumah Sakit, 2015). Keselamatan pasien menjadi isu yang sangat disukai oleh khalayak umum. Karena keselamatan pasien salah satu indikator penilaian terhadap suatu rumah sakit. Oleh karena itu rumah sakit dituntut agar mampu mengelola kegiatannya dengan mengutamakan pada tanggung jawab para professional di bidang kesehatan, khususnya tenaga medis dan tenaga keperawatan dalam menjalankan tugas dan kewenangannya. Tidak selamanya layanan medis yang diberikan oleh tenaga kesehatan dapat memberikan hasil yang sebagaimana diharapkan semua pihak. Tenaga kesehatan yang melakukan kelalaian dapat dapat disebut melakukan malpraktik. Malpraktik yang dilakukan oleh tenaga kesehatan dapat berupa malpraktik dibidang medik dan malpraktik medik. Karena banyaknya kasus malpraktik, maka harus diterapkan program keselamatan pasien (Mudayana, 2014).

Keselamatan pasien rumah sakit adalah suatu sistem dimana rumah sakit membuat asuhan pasien lebih aman yang meliputi asesmen resiko, identifikasi dan pengelolaan hal yang berhubungan dengan resiko pasien, pelaporan dan analisis insiden, kemampuan belajar dari insiden dan tindak lanjutnya serta implementasi solusi untuk meminimalkan timbulnya resiko dan mencegah terjadinya cedera yang disebabkan oleh kesalahan akibat melaksanakan suatu tindakan atau tidak mengambil tindakan yang seharusnya diambil (Pagala, Shaluhiyah, \& Widjasena, 2017).

Keselamatan adalah sesuatu hal yang membuat manusia khawatir di setiap 
langkahnya. Ketika seseorang berpergian pasti dirinya akan berpikir tentang keselamatan perjalananya. Begitu pula pasien yang datang berobat ke rumah sakit, ia datang dengan harapan agar sakit penyakit yang ia derita dapat segera membaik ketika dirawat sehingga ia dapat beraktivitas kembali.

\section{METODE}

Rancangan penugasaan kajian ini menggunakan buku teks, buku referensi, ebook, jurnal dengan menganalisa dan kajian bebas. Penelitian ini menggunakan jenis penelitian explanatory research. Penelitian eksplanatori ( explanatory research ) bersifat penjelasan dan bertujuan untuk menguji suatu teori atau hipotesis guna memperkuat atau bahkan menolak teori atau hipotesis hasil penelitian yang sudah ada.

\section{HASIL DAN PEMBAHASAN}

Menurut DepKesRI Keselamatan pasien rumah sakit adalah suatu sistem yang diterapkan untuk mencegah terjadinya cedera akibat perawatan medis dan kesalahan pengobatan melalui suatu sistem assesment resiko, identifikasi dan pengelolaan faktor risiko, pelaporan dan analisis insiden, kemampuan belajar dan tindak lanjut dari insident serta implementasi solusi untuk meminimalkan timbulnya risiko. Keselamatan pasien merupakan suatu sistem untuk mencegah terjadinya cedera yang disebabkan oleh kesalahan akibat melaksanakan suatu tindakan atau tidak mengambil tindakan yang seharusnya diambil (TKPRS RSUP Sanglah Denpasar, 2011).

Keperawatan merupakan profesi yang berfokus pada pelayanan terhadap pasien. Perawat harus mengerti dan memahami bahwa saat memberikan asuhan banyak resiko yang dapat mengancam nyawa pasien, untuk itu perlu kesadaran penuh saat melakukan asuhan keperawatan. Tingkat pengetahuan tenaga medis khususnya perawat sangatlah penting dalam meiaksanakan asuhan keperawatan. Semakin tinggi pengetahuan perawat tentang kode etik dan hukum kesehatan maka semakin baik pula kinerja perawat dalam melaksanakan asuhan keperawatan.

Upaya untuk menambahkan tingkat pengetahuan Perawat atau tenaga kesehatan yang lain yaitu melalui pelatihan atau seminar' Pelatihan dan seminar dapat bermanfaat untuk melakukan evaluasi terhadap program dan standar termasuk standar asuhan keperawatan. Standar asuhan keperawatan harus selalu ditinjau keakuratannya sehingga tidak terjadi suatu kesalahan yang dapat merugikan pasien, selain itu perawat harus dibina untuk 
mencapai kinerja yang professional dan bertanggung jawab.

Kejadian di rumah sakit tidak dapat diprediksi, banyak kemungkinan yang terjadi. Di rumah sakit terdapat berbagai macam obat, prosedur, tes, serta alat kesehatan dengan teknologi canggih yang jumlahnya tidak sedikit. Pelayanan kesehatan yang diberikan oleh tenaga profesi dan non profesi semakin kompleks seiring dengan berkembangnya ilmu pengetahuan dan teknologi. Hal tersebut memungkinkan terjadinya Kejadian Tidak Diharapkan (KTD) bila kompleksitas tersebut tidak dikelola dengan baik. Perawat sebagai tenaga kesehatan yang jumlahnya terbesar di rumah sakit (sebesar 40-60 \%) memiliki jobdesk yang dituntut untuk selalu menerapkan 6 Sasaran Keselamatan Pasien sehingga memiliki peran kunci dalam menentukan keberhasilan akreditasi JCI tingkat paripurna. Sikap perawat dalam mendukung penerapan 6 Sasaran Keselamatan Pasien sangat diutamakan untuk menjamin keselamatan pasien. Asuhan keperawatan memiliki peran yang sangat penting dalam mencegah KTD yang terjadi pada pasien dan lingkungan keperawatan. Jasa perawat dibutuhkan selama 24 jam oleh pasien sehingga memiliki waktu kontak paling banyak dibanding tenaga kesehatan lain untuk berhubungan dengan pasien (Pambudi, Desnani, \& Yasin , 2018).

Komunikasi yang baik antar petugas medis dengan pasien akan memberikan dampak yang positif terhadap mutu pelayanan kesehatan di suatu rumah sakit serta dimungkinkan menurunkan kesalahpahaman apabila terjadi kecelakaan. Komunikasi dapat dilakukan dengan metode SBAR. Kerangka komunikasi efektif yang digunakan di rumah sakit adalah komunikasi SBAR (Situation, Background,Assessment,Recommendation ), metode komunikasi ini digunakan pada saat perawat melakukan handover ke pasien. Komunikasi SBAR adalah kerangka teknik komunikasi yang disediakan untuk petugas kesehatan dalam menyampaikan kondisi pasien. SBAR adalah metode terstruktur untuk mengkomunikasikan informasi penting yang membutuhkan perhatian segera dan tindakan berkontribusi terhadap eskalasi yang efektif dan meningkatkan keselamatan pasien. SBAR juga dapat digunakan secara efektif untuk meningkatkan serah terima antara shift atau antara staf di daerah klinis yang sama atau berbeda

WHO menyebutkan bahwa ada beberapa faktor yang berhubungan dengan keselamatan yaitu:

- Komunikasi 
- struktur/proses kerja tim individual

- kesadaran situasi, pengambilan keputusan, stres, kelelahan

- lingkungan kerja yang berbahaya

Leape, Dineen, AHRQ, Depkes, Henrikson menyebutkan bahwa faktorfaktor yang berkontribusi terhadap terjadinya kejadian keselamatan pasien meliputi faktor karakteristik individu, sifat dasar pekerjaan, lingkungan fisik, interaksi antara sistem dan manusia, lingkungan organisasi dan sosial, manajemen, dan lingkungan eksternal.

\section{Perawat memiliki SOP yang} tujuannya agar tindakan yang dilakukan menjadi lebih valid dan sesuai dengan standar prosedur pengerjaannya. Jika perawat melakukannya sesuai dengan SOP maka tidak akan terjadi kesalahan, untuk itu lah perawat harus mengikuti SOP, jangan karena lagi malas, mempunyai masalah maka perawat tersebut tidak melakukan tindakan sesuai Standar Prosedur.

Hal yang dapat terjadi ketika perawat tidak melakukanya sesuai SOP maka jika terjadi kesalahan dengan tindakannya maka pasien/keluarga pasien dapat menuntut perawat tersebut, dapat terjadi malpraktik yang seharusnya tidak terjadi jika perawat melakukannya dengan tepat. Jika ada perawat yang begitu maka sebaiknya di lakukan pelatihan lagi kepada perawat yang bersangkutan agar dapat belajar lagi. kelalaian dan ataupun malpraktik. Pelayanan kesehatan yang bermutu yaitu pelayanan kesehatan yang dapat memuaskan setiap pemakai jasa pelayanan sesuai dengan kode etik dan standar pelayanan yang telah ditetapkan. Pelayanan perawatan yang sesuai dengan standar memiliki dampak yang lebih besar terhadap citra pelayanan rumah sakit.

Sasaran keselamatan pasien yaitu ketepatan identifikasi pasien, peningkatan komunikasi yang efektif, peningkatan keamanan obat yang perlu diwaspadai (highalert), kepastian tepat-lokasi tepat prosedur, tepat pasien operasi, pengurangan risiko infeksi terkait pelayanan kesehatan, pengurangan risiko pasien jatuh.

Beberapa tren dan isu penyebab keselamatan pasien dapat terancam ialah:

- Kesalahan dalam mengidentifikasi pasien.

- Komunikasi yang tidak efektif,

- Penggunaan obat high alert yang tidak aman

- Tidak tepat lokasi, prosedur, dan pasien operasi,

- Pencegahan risiko infeksi yang buruk,

- Pencegahan pasien jatuh yang buruk. 
Keselamatan pasien rumah sakit adalah suatu sistem dimana rumah sakit membuat asuhan pasien lebih aman. Sistem tersebut meliputi penilaian risiko, identifikasi dan pengelolaan hal yang berhubungan dengan risiko pasien, pelaporan dan analisis insiden, kemampuan belajar dari insiden dan tindak lanjutnya serta implementasi solusi untuk meminimalkan timbulnya risiko.

\section{KESIMPULAN}

Keselamatan Pasien menjadi Isu dan Tren yang sangat sering di bahas. Keselamatan pasien bergantung kepada pemberi pelayanannya seperti perawat, dokter, tenaga medis yang lain. Semakin tinggi pengetahuan yang dimiliki perawat dalam melakukan tindakan, maka semakin besar angka keselamatan pasien. Semakin perawat peduli dan tidak lalai dengan asuhan keperawatan yang dia lakukan maka pelayanan yang diterima pasien lebih besar.

\section{DAFTAR PUSTAKA}

Cahyono, A. (2015). Hubungan

Karakteristik dan Tingkat

Pengetahuan Perawat Terhadap

Pengelolaan Keselamatan Pasien di Rumah Sakit.

Dewi, Y. A. (2017). Faktor-Faktor yang mempengaruhi penerapan sasaran keselamatan pasien pada perawat diruang rawat inap kelas I,II,II

RSUD Dr.Soedirman Kebumen.

Fadriyanti, Y., \& Suryarinilsih, Y. (2018). HUBUNGAN JAM KERJA DAN KARAKTERISTIK PERAWAT PELAKSANA DENGAN.

Isnaini, N. (2014). Pengalaman perawat pelaksana dalam menerapkan keselamatan pasien. Jurnal Manajemen Keperawatan.

Mudayana, A. A. (2014). PERAN ASPEK ETIKA TENAGA MEDIS DALAM PENERAPAN.

Pagala, I., Shaluhiyah, Z., \& Widjasena, B. (2017). Perilaku Kepatuhan Perawat Melaksanakan SOP terhadap kejadia Keselamatan Pasien di RS X Kendari. Jurnal Promosi Kesehatan Indonesia.

Pambudi, Y. D., Desnani, D., \& Yasin, D. D. (2018). Faktor-Faktor Yang Mempengaruhi Perawat Dalam Penerapan 6 Skp (Sasaran Keselamatan Pasien) Pada Akreditasi Jci (Joint Commission International) Di Ruang Rawat Inap Rumah Sakit Panti Waluya Malang. Nursing News.

Simamora, R. H. (2018). Buku ajar keselamatan pasien melalui timbang terima pasien berbasis 
komunikasi efektif: SBAR. Medan:

USUpress.

Simamora, R. H., \& Fathi, A. (2019). The Influence Of Training Handover Based SBAR Communication For Improving Patients Safety. Indian journal of public health research \& development, 10(9), 1280-1285.

Simamora, R. H., \& Nurmaini. (2019).

Knowledge of Nurses about

Prevention of Patient Fall Risk in

Inpatient Room of Private Hospital

in Medan. Indian Journal of

Public Health Research \&

Development. 